\title{
Tekfurdağlı Bir Âlim; Osman Nuri Efendi ve İcâzet-nâmesi
}

\author{
Yrd. Doç. Dr., Karabük Üniversitesi İlahiyat Fakültesi \\ Asst Prof, Karabuk University, Theology Faculty \\ Orcid ID: 0000-0003-0733-8939 \\ nevzatsaglam@karabuk.edu.tr
}

Nevzat Sağlam

\section{Öz}

Âlimler milletlerin dinî ve ilmî hayatını inşa eden manevi mimarlarıdır. Bu seçkin zevatın gayretleri ve hizmetleri ile ilim ve irfan nesilden nesile aktarılmıştır. Böylece erdemli insanlar yetiştirmek mümkün olmuştur. Osmanlının her döneminde ilmin inkişafına katkıda bulunmuş yüzlerce âlim yetişmiştir. Bunlar gösterdikleri çabalarla içinde yaşadıkları toplumu cehaletin karanlığından kurtarmaya çalışmışlardır. Hafız Osman Nuri Efendi de Osmanlının son döneminde yaşamış, Maydos/Eceabâd ve Tekirdağ müftülüklerinde bulunmuş, müderrislik yapmış bir âlimdir. Bu çalışmada Osman Nuri Efendi'nin Meşihat Arşivi'nde bulunan belgeler ışığında biyografisi ve icâzet-nâmesi ele alınmıştır. Bu çerçevede Tekirdağ doğumlu olan Osman Nuri Efendi'nin memuriyetleri ve hocaları, okuduğu dersler, tahsilini tamamladıktan sonra aldığı icâzetnâmenin tercümesine yer verilmiştir.

Anahtar Kelimeler: Osman Nuri, Tekfurdağ, İcâzet, Müderris, Müftü.

\section{Osman Nuri Effendi, a Scientist of Tekfurdag; and His Ijazatnamah (License to Teach)}

\begin{abstract}
Scholars are spiritual architects who have built the religious and scientific life of the community. This eloquent pleasure and services and knowledge and knowledge are transferred from generations to generations. Thus, it was possible to cultivate virtuous people. They have tried to save the society in which they live by the darkness of ignorance. Hafiz Osman Nuri Efendi is a scholar who lived in the last period of the Ottoman Empire and was found in the muftis of Maydos/Eceabad and Tekirdag. In this study, Osman Nuri Efendi's documents in the Archive of Meshihat were handled in the light of biography and ijazatnamah. Osman Nuri Efendi, who is born in Tekirdağ in this frame, has his translations of civil servants and prosperity, the lessons he has read, and the ijazatnamah he received after he completed his college education.
\end{abstract}

Keywords: Osman Nuri, Tekfurdag, Ijazatnamah, Mufti, Tutor. 


\section{Giriş}

Osmanlı dönemi devlet teşkilatında başta Şeyhülislâm, nakibüleşraf, kazasker, kadı ve müderris gibi meslek sahipleri ulemâ sınıfı içinde sayılmışlardır. Bu sinıfa dâhil olanlar, kökleşmiş bir eğitim kurumu olan medresede tahsillerini tamamlayıp icâzet alarak mezun olduktan sonra merkezî bürokrasinin yanı sıra müderrislik kadılık ve müftülük gibi dinî hizmetlerde görev almışlardır. Toplumda itibar ve saygınlıkları bulunan müderrislerin asıl vazifesi talebeleriyle ilgilenmek ve onları ilme teşvik etmek idi. Bununla beraber kendilerine teftiş, tahkikat ve hakemlik gibi bazı görevler de tevdi edilmekteydi. ${ }^{2}$ Müderrisler tefsir, hadis, fıkıh, kelam, gibi ulûm-i 'âliye yanında mantık, sarf, nahiv gibi ulûm-i 'âliye dersleri de okutuyorlardı. Müderrisler camilerde genellikle sabah namazıyla öğle namazı arasında her kesimden halka dersiâm olarak da ders vermekteydi. ${ }^{3}$

Diğer taraftan mülkî, beledî, askerî ve adlî alanları içine alacak kadar çok geniş bir görev sahası olan kadılar da ilmiye sınıfı içinde yer almaktaydılar. ${ }^{4}$ Bir bakıma taşrada kadının yardımcısı ve ondan sonra ilmiye sınıfının birer temsilcisi olan müftüler ise kendilerine sorulan dinî meselelere ilmî salahiyetlerine dayanarak sözlü veya yazılı olarak cevap verme yetkisine sahip kişilerdi. ${ }^{5}$ Bir kaza veya vilayette boşalan müftülük görevi için idare meclisi tarafından ulema sınıfına mensup adaylar arasından seçim yapılmakta ve seçim sonucu Meşihat'e bildirilmekteydi. Meşîhat tarafından yapilan değerlendirmede genellikle en fazla oy alan kişi müftü olarak tayin edilimekteydi. Müftüler bulundukları yerlerde dinî hizmetlerin sağlıklı yürütülmesi ve halkın dini sorularının cevaplandırılmasıyla yükümlü idiler. ${ }^{6} \mathbf{1}$.

\section{Osman Nuri Efendi'nin Doğumu ve Tahsili}

Hafız Osman Nuri Efendi 1282/1866-67 tarihinde Tekirdağ/Tekfurdağı'nda doğmuştur. Osman Lazı olarak bilinmektedir. ${ }^{7}$ Babası zabıt çavuşlarından müteveffâ Halil Efendi, dedesi ise Ali'dir. Annesi Nefise Hanım'dır.

\footnotetext{
${ }^{1}$ Mehmet İpşirli, “İlmiye”, DIA, İstanbul 2000, c. 22 s. 141.

2 Mehmet İpşirli, “Müderris”, DİA, İstanbul 2006, c. 31, s. 470.

${ }^{3}$ Mehmet İpşirli, "Dersiâm”, İstanbul 1994, c. 9, s. 186; Mehmet Zeki Pakalın, Osmanlı Tarih Deyimleri ve Terimleri Sözlü̆ğ̈̈, İstanbul MEB, c. II, s. 598.

${ }^{4}$ Mehmet Zeki Pakalın, age., c. II, s. 122-125; İlber Ortaylı, “Kadı”, DİA, İstanbul 2001, c. 24, s. 69.

${ }^{5}$ Mehmet Zeki Pakalın, age., c. II, s. 599.

${ }^{6}$ Düstur, c. 9, 2. Tertip, İstanbul 1928, s. 690-691; Sadık Albayrak, Son Devir Osmanlı Ulemâsı, İstanbul Büyükşehir Belediyesi Kültür İşleri Daire Başkanlığı Yayınları, İstanbul 1996, c. s. 39. 7 İST. MFT, MŞH, SAİ, 62/19-1.
} 
Osman Nuri Efendi'nin başarılı bir öğrenci olduğu o dönemdeki not döküm belgesinde açıç̧a görülmektedir. Tekfurdağı'nda geleneksel usulle Kanlı Mescid ibtidâî mektebinde hafızlığını tamamladıktan sonra yeni açılan Feyziyye Mektebi'ne girmiş ve buradan birincilikle mezun olmuştur. Arkasından 1301/1885-86'de Tekfurdaği'nda bulunan ve rüştiye mektebine dönüştürülen Rüstem Paşa Medresesi'ni de ikincilikle bitirmiştir. Nitekim Tekfurdağ 1 Rüştiye Mektebi'nde tahsili zorunlu derslerin tamamından yüz dört puan almış, bu üstün başarısı sebebiyle kendisine kabulü mümkün olan mekteplerden istediğine imtihansız girme hakkı verilmiştir. ${ }^{8}$ Tekfurdağı Maarif Meclisi tarafından da tasdik edilmiş olan diplomasındaki notları şöyledir:

\begin{tabular}{|l|l|l|l|l|l|l|l|l|l|}
\hline Farisî & Hesap & Hendese & Türkçe & Belagat & Tarih & Hat & Resim & Fransızca & Top. \\
\hline 10 & 10 & 9 & 10 & 9 & 9 & 10 & 9 & 8 & 104 \\
\hline
\end{tabular}

Bilahare tahsilini tamamlamak üzere İstanbul'da Şehid Mehmed Paşa Medresesi'nde ulûm-i 'âliye (sarf, nahiv, belagat, mantık gibi ilimler) ve ulûmi 'âliye (Tefsir, hadis, fıkıh, kelam gibi ilimlerin) tedrisine başlamıştır. Bir süre sonra eğitimine Şehzâde Medresesi'nde devam etmiş ve Bayezid Camii'nde Firecikli Lütfi Efendi'nin ders halkasına girmiştir. Burada önce Bayezid dersiâmlarından Kalaycıklı Hacı Hâfız Efendi'nin ikindi derslerine, sonra Sirozlu Hacı Eyub Efendi'nin derslerine devam etmiş, 1315/1897-98 yılında tahsilini tamamlayarak icâzet-nâme almıştır. Arapça ve Farsça dillerine konuşup, yazacak derecede hâkim idi. ${ }^{9}$

Osman Nuri Efendi'nin tasavvufla da ilgisi olmuştur; Kilidbahir'de Nakşibendî Tarikati'nin Hâlidiye koluna mensup Kazanlıklı Hacı Ahmed Efendi'nin yoluna girmiş, 1317/1899'da ona halef olacak mertebeye yükselmiştir. ${ }^{10}$ Kendi imzasıyla verdiği terceme-i hal evrakında "Kilidü'l-Bahr'de Makarr-1 Meşâyihi Nakşibendiyye-i Hâlidiyye'den Tekfurdâğî Osman Nuri b. Halil" ifadesi yer almaktadir.

Nüfus müdürlügünden verilen tezkire-i Osmânî'de Hafız Nuri Efendi'nin 1282 senesinde Tekfurdağı'nda doğduğu, babası müteveffâ Halil, annesi Dersaadet'te mukîm Nefîse Hanım, evli ve talebe-i ulûmdan olduğu kaydedilmektedir. Osman Nuri Efendi'nin orta boylu, ela gözlü, buğday tenli olduğu, Eceâbâd kazası, Kilidülbahr Hoca Bayezid Mahallesi sekizinci hane, Yabancı Sokak altmış numaralı meskende ikâmet ettiği belirtilmektedir. ${ }^{11}$

8 İST. MFT, MŞH, SAID, 62/19-3. 23 Mayıs 1885. Osman Nuri Efendi'nin biyografisine ilişkin bir çalışmada terceme-i hal evrakından kısa bilgi verilmiştir, bk. Sadık Albayrak, age., c. 4, s. 192.

9 İST. MFT, MŞH, SAİD, 62/19-1. 15 Eylül 1909.

10 İST. MFT, MŞH, SAİ, 62/19-1,2. 15 Eylül 1909.

11 İST. MFT, MŞH, SAID, 62/19-4.

Türkiye İlahiyat Araştırmaları Dergisi Turkey Journal of Theological Studies

[Tiad-2602-3067]
Cilt / Vol : 2,

Sayı/Issue: 1 , 2018 


\section{Bulunduğu Görevler}

Uzun süre devlet hizmetine girmemiş, ancak 1325/1909 tarihinde Gelibolu Sancağı'na bağlı Eceâbâd kazası meclisi tarafından Eceâbâd müftüsü seçilmiş, 6 Nisan 1910 tarihinde Meşihat'in menşûrundan sonra görevine başlamıştır. ${ }^{12}$

Osman Nuri Efendi, görev yaptığı yıllarda ayaklarından, dizlerinden ve kulaklarından birtakım rahatsızlıklar yaşamıştır. Nitekim üç yıldır romatizmadan mütevellid dizlerinden ve ayaklarından rahatsız olduğunu belirterek tedavi amacıyla Bursa kaplıcalarına gitmek için iki ay izin talebinde bulunmuştur. Gelibolu Belediye tabibi tarafından yapılan muayenede Osman Nuri Efendi'nin rahatsızlı̆̆ teşhis edilmiş, kaplıca mevsimi geçtiğinden havası kuru bir yerde bir müddet istirahat etmesi tavsiye edilmiştir. ${ }^{13}$ Bunun üzerine Osman Nuri Efendi'ye Meşîhat tarafından iki ay izin verilmiştir. ${ }^{14}$ Íki aylık iznin arkasından rahatsızlı̆̆ı geçmediğinden ve ameliyat olması gerektiğinden izni bir ay daha uzatılmıştır. ${ }^{15}$ Yine Osman Nuri Efendi her iki kulağındaki rahatsızlık sebebiyle uzun süre tedavi gördüyse de iyileşmediği binbaşı baştabip tarafından verilen raporda ifade edilmiştir. ${ }^{16} \mathrm{Bu}$ sebeple kulak mütehassısı bir doktor tarafından tedavi edilmesi gerektiği, bunun için de iki/üç ay izne ihtiyacı olduğu belirtilmiştir. ${ }^{17}$ Tekfurdağı'nda kulak mütehassısı bir tabip tarafından tedavi altına alınan Hafız Osman Nuri Efendi'nin izni tedavisinin tamamlanabilmesi için iki ay daha uzatılmıştır. ${ }^{18}$

Diğer taraftan istenen ilmî vasıflara sahip olması sebebiyle 11 Ramazan 1334/12 Temmuz 1916 tarihinde ibtidâ-i dâhil Bursa müderrisliği pâyesi verilmiş olan ${ }^{19}$ Osman Nuri Efendi'ye, mevcut maaşıyla ailesini geçindirmekte sıkıntı çektiğinden müftülük görevine ilaveten Meşihat tarafından 3 Kasım 1917 tarihinden itibaren iki yüz kuruş maaşla münhal olan Eceabâd müderrisliği tevcih edilmiştir. ${ }^{20}$

Kadılık, hâkimlik, müftülük ve imamlık gibi dinî ve adli hizmetlerin yürütülmesiyle görevli şahısların zaman zaman meslekleriyle ve kişilikleriyle bağdaşmayan davranışlarda bulunduklarından görevlerine son verilmiştir.

\footnotetext{
12 İST. MFT, MŞH, SAİ, 62/19-2. 21 Mart 1910.

13 İST. MFT, MŞH, SAİ, 62/19-7.

14 İST. MFT, MŞH, SAİD, 62/19-6, 8. (4 Eylül 1915).

15 İST. MFT, MŞH, SAİ, 62/19-9. (29 Ocak 1916).

16 İST. MFT, MŞH, SAİD, 62/19-12. (8 Nisan 1917).

17 İST. MFT, MŞH, SAİD, 62/19-13, 14. (14 Nisan 1917).

18 İST. MFT, MŞH, SAİ, 62/19-15, 16. (16 Ağustos 1917).

19 İST. MFT, MŞH, SAİD, 62/19-10. (7 Ağustos 1916).

20 İST. MFT, MŞH, SAİD, 62/19-11. (23 Ekim 1917).
} 
Tekfurdağ1 Müftüsü Ömer Raci Efendi de mesleğiyle bağdaşmayan davranışlarda bulunduğuna dair şikâyetler sebebiyle görevinden alınmıştır. Ancak siyasi problemler ve ihtilaflar sebebiyle yerine müftü tayin edilecek kişi ile ilgili toplumda bir çekişme yaşandığ görülmektedir. Nitekim Tekfurdağ 1 Kadısı Meşîhat'e yazdığı arzuhalde, Ömer Raci Efendi'nin görevden alınmasıyla halkta memnuniyet olmakla birlikte, müftülük için ittihatçıların Sarıklı Avukat Hilmi Efendi'yi istediklerini, halktan bazılarının taşradan bazı şahısların müftülüğe tayini konusunda mütereddit olduklarını belirtmektedir. Ancak Avukat Hilmi Efendi'nin müftülüğe ehil olmadığını, İttihat ve Terakkinin ateşli bir taraftarı olduğunu, bu sebeple müftü tayin edilmesinin memleket için bir felaket olacağını belirtmektedir. Diğer taraftan Şam ulemâ ve fukahâsından ve Eyyûbî-zâdelerden Hoca Tevfik Efendi'nin müftülüğe daha layık olduğunu ifade etmektedir. Bu şahsın ilmi, dindarlığı, ahlakı ve sayısız üstün meziyetleriyle halk nezdinde değer ve itibar kazandığ vurgulanmaktadır. Bu yönüyle kendisinden istifade edilebileceği belirtmektedir. Bu sebeple Meşihat'in bu zâtı müftü tayın etmesinin isâbetli olacağını Tekfurdağ kadısı açıkça ifade ve beyan etmektedir. ${ }^{21}$ Durumun hassasiyeti ve nezaketine binaen Meşihat tarafından 1 Nisan 1919 tarihinde Edirne vilayetine gönderilen tahriratta Tekfurdağı müftüsü Ömer Raci Efendi'nin mesleğiyle bağdaşmayan ahvalinden dolayı azliyle münhal olan Tekfurdağı Müftülüğü için usulüne uygun ve tarafsız bir seçim yapılması istenmiştir. ${ }^{22}$

Kadı, mutasarrıf, muhasebeci, tahrirat müdürü, ziraat memuru ve diğer âzâlardan oluşan Mahallî İdare Meclisi tarafından istekli adaylar arasında bir seçim yapılmıştır. Bu seçimde üç adaydan biri olan müderrisinden sâbık Maydos/Eceabâd Müftüsü Osman Nuri Efendi dokuz rey alarak diğerlerinin önüne geçmiştir. ${ }^{23}$ Kadı tarafından müftülüğe daha layık olduğu belirtilen Şamlı Mehmed Tevfik Efendi ise, yedi oy almıştır. Edirne valisi tarafından seçim evrakları Meşihat'e gönderilmiş, üyelerden çoğunun oyunu almış olan Osman Nuri Efendi bin iki yüz elli guruş maaşla 21 Mayıs 1919'da Tekirdağ Müftülüğ̈̈'ne tayin edilmiştir. ${ }^{24}$

Tekfurdağı Müftüsü Osman Nuri Efendi'nin aylık bin beş yüz kuruş olan maaşını Haziran 1336/1920 sonuna kadar Tekfurdağı Mal Sandığı'ndan aldığ1, ilişiğinin ve alacağının kalmadığı belirtilmektedir. ${ }^{25}$ Ancak 20 Temmuz 1920 tarihinde Tekfurdağı'nın Yunanlılar tarafından işgaline kadar on dokuz günlük maaşı ile kararname gereği verilmesi öngörülen Ağustos'a kadarki on iki

21 İST. MFT, MŞH, SAİ, 62/19-21, 25. (30 Mart/1 Mayıs 1919).

22 İST. MFT, MŞH, SAID, 62/20. 1 Nisan 1919.

23 İST. MFT, MŞH, SAID, 62/19-23. (5 Nisan 1919).

24 İST. MFT, MŞH, SAİ, 62/19-26.

25 İST. MFT, MŞH, SAID, 62/19-30. (24 Temmuz 1920).

Türkiye İlahiyat Araştırmaları Dergisi

Turkey Journal of Theological Studies

[Tiad-2602-3067]
Cilt / Vol : 2,

Say1/Issue: 1, 2018 
Tekfurdağlı Bir Âlim; Osman Nuri Efendi ve İcâzet-nâmesi/ Osman Nuri Effendi, a Scientist of Tekfurdag; and His Ijazatnamah (License to Teach)

günlük maaşının verilmesini talep etmiştir. ${ }^{26}$ Başka bir arzuhalde ise yine 20 Temmuz 1920 tarihinde Yunan işgali sebebiyle alamadığı maaşının Dersaadet Adliye Umûr-i Zâtiye Müdür Muavini Nazif Bey'e verilmesini talep etmiştir. ${ }^{27}$ Ancak Meşihat'ten verilen cevapta, memurların işgal tarihine kadar olan alacaklarının mahallî maliye memurları tarafından hazineye verilecek raporlara dayanılarak tahakkuk yapılacağı, işgal tarihinden sonraki maaşlara ilişkin ise muhasebe-i umumiyenin şimdilik bir işlem yapılmaması doğrultusundaki emri sebebiyle talebinin yerine getirilemeyeceği belirtilmiştir. ${ }^{28}$

Yunan işgali sebebiyle görev yerini terk eden memurlar hakkında yapılan tahkikat çerçevesinde Osman Nuri Efendi'nin de sorgulandığı anlaşılmaktadır. Nitekim 27 Eylül 1921 tarihli beyannamede kendisine yöneltilen sorulara şu cevapları verdiği anlaşılmaktadır:

\begin{tabular}{|l|l|}
\hline İsim ve şöhretiniz & Osman Nuri Efendi \\
\hline $\begin{array}{l}\text { Sıfat ve mahall-i } \\
\text { memuriyetiniz }\end{array}$ & Tekfurdağ Müfettişliği \\
\hline Miktar-ı maaşınız & Bin beş yüz kuruş \\
\hline $\begin{array}{l}\text { Son aldığınız maaş } \\
\text { hangi aya aittir? }\end{array}$ & Haziran 1336/Haziran 1920 mâhına aittir \\
\hline $\begin{array}{l}\text { Mahall-i } \\
\text { memuriyetinizden ne } \\
\text { vakit ve ne gibi bir } \\
\text { tebliğ ile ayrıldınız? }\end{array}$ & $\begin{array}{l}\text { İsgal üzerine müslümanların hukukuyla evkâf-1 } \\
\text { maksadıyla ahâlî tarafından gösterilen ibrâm } \\
\text { üzerine ve makâm-ı celîl-i Meşîhat'e mütemeyyiz } \\
\text { ricâl-i ilmiyyemiz vasıtasıyla iblâğ-1 keyfiyet } \\
\text { edilerek mahall-i memuriyetimden ayrıldım. El- } \\
\text { Yevm müfettişlik makamında Tekfurdağı'nda } \\
\text { bulunmaktayım. }\end{array}$ \\
\hline
\end{tabular}

26 İST. MFT, MŞH, SAID, 62/19-29. (25 Haziran 1920).

27 İST. MFT, MŞH, SAID, 62/19-28. (10 Temmuz 1920).

28 İST. MFT, MŞH, SAİD, 62/19-28. (19 Ağustos 1920).

Türkiye İlahiyat Araştırmaları Dergisi 


\begin{tabular}{|c|c|}
\hline $\begin{array}{l}\text { Mahall-i } \\
\text { memuriyetinizi terke } \\
\text { mezun olduğunuza } \\
\text { dair elinizde vesika } \\
\text { var mıdır ve nereden } \\
\text { verilmiştir? }\end{array}$ & \\
\hline $\begin{array}{l}\text { Hangi tarik ile } \\
\text { gelinmiştir? }\end{array}$ & \\
\hline $\begin{array}{l}\text { Birlikte diğer memurin } \\
\text { gelmiş midir? }\end{array}$ & - \\
\hline \multicolumn{2}{|c|}{$\begin{array}{l}\text { Ber-vech-i bâlâ ita eylediğim izâhât muvafık-1 hak ve hekîkat olup, aks } \\
\text { tebeyyün ederse } 28 \text { T.sânî 328/11 Aralık } 1912 \text { tarihli talimat ve dördüncü } \\
\text { madde ile tatbik edilecek muameleye bilâ itirâz mutâvaat edeceğim } \\
\text { mübeyyin işbu beyannâme bi't-tanzîm Meşîhat-i celîle memurîn müdiriyet- } \\
\text { aliyyesine takdîm kılındı. }\end{array}$} \\
\hline & Tekfurdağı Müftüsü \\
\hline & Ulemâdan Osman Nuri \\
\hline & 27 Eylül 336/27 Eylül 1920 \\
\hline \multicolumn{2}{|c|}{$\begin{array}{l}\text { İşbu beyannâme zîrine mevdûe imza Tekfurdağı Müftüsü Osman Nuri } \\
\text { Efendi'nin olduğu ve münderecât-1 beyannâme bi-temâmihâ muvafık-1 } \\
\text { hakîkat bulunması cümlemizce müsellem bulunmakla vukû-i hâli beyânen iş } \\
\text { bu mahalle şerh verilerek tasdik kılındı. }{ }^{29}\end{array}$} \\
\hline & $\begin{array}{l}\text { Tekfurdağı Muhâseb-i Livâ Merkez Kâtibi } \\
\text { Tekfurdağı Bidâyet Makemesi Birinci Kâtibi }\end{array}$ \\
\hline
\end{tabular}

Bu beyannâmeden de anlaşılacağı üzere Tekfurdağı Müfettişi Osman Nuri'nin işgal yıllarında kendi ifadelerine göre memuriyet mahallinden müslümanların hukukunu ve İslam vakıflarının korunması maksadıyla halkın ısrarıyla Meşîhat makamının da bilgisi dâhilinde ayrıldığı, halen müfettişlik makamında Tekfurdağg'nda bulunduğunu belirtmektedir. ${ }^{30}$ Buradan işgal yıllarında görev yerlerini terk eden memurların devlet tarafından sorgulandığı ve kendilerinden beyannâme alındığı anlaşılmaktadır. Bilindiği üzere Tekirdağ Balkan Savaşlarında 1912'de Bulgar işgaline uğramış, 1913 yılında düşman işgalinden kurtarılmıştır. I. Dünya savaşından sonra da Mondros Mütarekesi'nin verdiği

29 İST. MFT, MŞH, SAİ, 62/19-5.

30 İST. MFT, MŞH, SAID, 62/19-5. 
Tekfurdağlı Bir Âlim; Osman Nuri Efendi ve İcâzet-nâmesi/ Osman Nuri Effendi, a Scientist of Tekfurdag; and His Ijazatnamah (License to Teach)

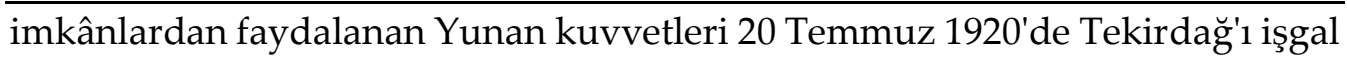
etmiş ise de 13 Kasım 1922'de Yunan işgali sona erdirilerek Türk yönetimine geçmiştir. İşgal yıllarında memurlar vazifelerini yapamamışlar görev mahallerini terk etmek zorunda kalmışlardır.

\section{Osman Nuri Efendi'nin İcazet-nâmesi}

İlk olarak hadis ilminde yazılı veya sözlü rivayet için izin vermeyi ifade eden icâzet, en kısa tanımıyla bir âlimin/hocanın talebesine ilmini aktarmasıdır. ${ }^{31}$ Medreselerin kuruluşuna kadar eğitim ve öğretime dayalı olmaksızın verilen izin ve izin belgesi anlamında kullanılırken, medreselerin kuruluşundan sonra bir eğitim ve öğretim disiplini içinde ilim ve rivayet nakletme yetkisi tanıyan belge anlamında kullanılmaya başlanmıştır. Önceleri hadis, siyer ve megāzî kitaplarına verilen icâzet zamanla sarf, nahiv, mantık, edebiyat, tarih, fikıh, tefsir, ferâiz, kelam ve riyâzî ilimlerde bir müderrisin dersine devam ederek tamamlayan talebenin derslere devam ettiğini, okuduğunu ve okutmaya yetkili olduğunu belgelemek üzere talebi üzerine hocası tarafından kendisine verilen belgedir. ${ }^{32}$

Bir icâzette icâzet veren hoca, icâzet talebinde bulunan veya icâzet verilen talebe, icâzete konu olan ve nakline izin verilen ilim, kitap, bir de izin ve onayı gösteren sözlü veya yazılı ifadesi olmak üzere dört unsur bulunmaktadır. Kapatıldıkları 1924 tarihine kadar Osmanlı medreselerinde ulûm-i eâliye ve ulûm-i âliyede "tekmîl-i nüsah" eden/tahsilini tamamlayan öğrencilerin ilmî yeterliliğini belgelemek üzere imtihandan geçirildikten sonra icâzet-nâme düzenlenmesi bir gelenek olmuştur. Bu icâzet-nâmeyi alanlar müderris, kadı ve müftü olarak görevlendirilmekteydi. ${ }^{33}$

Genellikle Arapça olarak yazılmış olan icâzet-nâme metinlerinde besmeleden sonra, Allah'a hamd, Hz. Peygamber'e salât ve selâm, ashabına duâdan sonra ilim öğretmenin ve öğrenmenin önemi, fazileti ayet ve hadisler ışı̆̆ında ifade edilmektedir. İlim talebesinin adı, ilmi gayreti, ehliyet ve liyakati belirtildikten sonra, icâzet veren hocasının hangi ilimleri okuttuğu, kendisinin ve hocasından itibaren Hz. Peygamber'e kadar ilim aldığı hocaları silsile olarak zikredilir. Tahsil ettiği ilmi öğretmek üzere talebesine hocası tarafından izin verildiği icâzet-nâmede ifade edilir. Ayrıca ilimle meşgul olması, talebelerine iyi davranması, vaktinin kıymetini bilmesi konusunda nasihatlerde bulunulur ve

\footnotetext{
31 Cemil Akpınar, "İcâzet", DİA, XXI, 2000, s. 393.

32 Cemil Akpınar, "agm", s. 394.

33 Cemil Akpinar, "agm", s. 397.
} 
kendisine dua etmesini ister. İcâzet-nâmenin sonunda hocanın imzası, mührü ve tarih yer alır.

\section{Bismillahirrahmanirrahim}

Bize bilmediklerimizi öğreten ve ilim talimiyle bizi mesut kılan ve ikramda bulunan Allah'a (cc) hamd, ümmetlere rehber, mürşit olan Hz. Muhammed (sav)'e ve nebiyy-i muhteremin şeriatını bilen ashabının üzerine salât ve selâm olsun.

Bil ki, Allah seni de bizi de kendisine itaate muvaffak kılsın. Yüce makamlara, yüksek kerâmetlere ve ebedi saadete ulaşmak için Allah'ın muvaffakiyeti sebeptir. Allah âlim ve şerîftir. Hz Peygamber: "Her kim ilim talep etmek maksadıyla bir yola girerse, Allah ona Cennet yollarından bir yolu kolaylaştırır. Melekler yaptığına rıza göstererek ilim talebesine kanatlarını gererler. Kişi ilim yolunda olduğu sürece yerde ve gökte olanlar, hatta denizde balıklar dahi onun için istiğfarda bulunurlar. Âlimin abide üstünlüğü dolunayın diğer yıldızlara üstünlüğü gibidir. İlimsiz âbid kirişsiz yay gibidir. Âlimler peygamberlerin vârisleridir. Kim dinde fakîh olursa Allah dini ve dünyası konusunda ona yeter. Allah Teâlâ şöyle buyurmuştur: "Senin üzerinde O'nun fazlı ve ihsanı çoktur. Allah Teâlâ ilmin değeri ve fazileti ile ilgili şöyle buyurmuştur: "Allah sana Kitap ve hikmet indirmiş, sana bilmediğini öğretmiştir. Allah'ın sana olan nimeti ne büyüktür." 34 Yine: "And olsun ki, Davud'a ve Süleyman'a ilim verdik. İkisi 'Bizi mümin kullarının çoğundan üstün kılan Allah'a hamdolsun' dediler. ${ }^{35}$ Başka bir âyet-i celîlede ise: Allah, içinizden inanmış olanları ve kendilerine ilim verilenleri derecelerle yükseltsin. Allah işlediklerinizden haberdardır. ${ }^{36}$

Bundan sonra kadîr olan rabbinin lütfuna muhtaç olan kul der ki; "Salihlerin yolunda, faziletlilerin ayaklarının tozu olan Muhammed Lütfi b. Ahmed elFirecikî; kader onu Kostantiniyye'ye sevk ettiğinde Allah onu âfet ve belalardan korudu. Güzel ahlak ve temiz nefis sahibi dayım Hacer-zâde olarak bilinen Receb Hayri Efendi b. Muhammed Ali (Allah onun mükâfatını artırsın ve makamını Cennet kılsın) himayesinde Kuran'ı talime başladım. Ondan tefsir hadis, münâzara ve diğer 'âlî/yüce ilimleri tahsil ettim. İlim talebiyle seherlerde fikir dalgalarına dalarak ilme yapıştım. Parmakla gösterilen faziletli kişilere müracaatta gayret sarf ettim. Seçkin talebelerime öğrendiklerimi öğretmek üzere büyük âlimler bana yazılı ve sözlü olarak icazet verdiler. Benim ders halkama devam eden, dinde âlim, kâmil, fâzıl âmil, manevi evladım kardeşim, salih kişi, (Allah sa 'yini meşkûr eylesin), Osman Nureddin Efendi ibn Halil etTekfurdâğî benden icazet talep etti. Benden aklî ve naklî ilimleri tahsil edince onu imtihan ettim ve onu yeterli, icâzete lâyık buldum, bunun üzerine ona

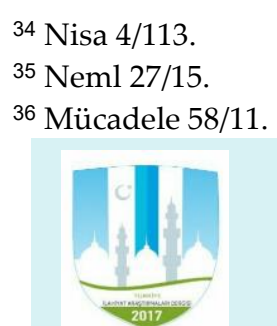

Türkiye İlahiyat Araştırmaları Dergisi Turkey Journal of Theological Studies [Tiad-2602-3067]

Cilt / Vol : 2, Say1/Issue: 1, 2018 
derslerden sonra beni hatırlamak ve hayır duâda unutmamak şartıyla ona icazet verdim. Ona salah, tedbir ve takvayı tavsiye ediyorum. Aklî ve naklî ilimlerde hocam dayanağım, zamanının biriciği faziletli, âlim, takva sahibi tahkik meydanının süvarisi, ilimde otorite, araştırmacı, âlimlerin lideri kıdvetül-ulemâ Balıkesirli Hacı Muhammed oğlu Seyyid Hafız Ahmed Nureddin Efendi bana icazet verdiği gibi ben de ona icazet verdim. Ona da derin ilim ve kemal sahibi hocası talebeler ve üstadlar arasında Kara Halil Efendi olarak bilinen es-Seyyid Halil b. Hasan es-Samsûnî (Allah onun mekânını güzel, makamını Cennet eylesin) ona da fazilet, kemal ve ilim sahibi Müzlif/Müzellif Ahmed Efendi olarak meşhur olan es-Seyyid Ahmed b. İbrahim el-Kütahyevî (Allah onu makamını nurlandırsın ve Cennet kılsın) ona da güzel ahlakla muttasıf ilimleri kendisinde toplamış Abdurrahman Efendi b. el-Hâc Yusuf el-Evlevî (?) (Allah kabrini nurlandırsın) ona da zamanının en faziletlisi ve en âlimi hocası ve kardeşi ve Hacı Emir-zâde olarak meşhur Muhammed b. Alhed el-Güzelhisârî, o da fazilet ve ilim sahibi Muhammed elHafîd en-Nisârî'den icâzet almıştı. O da âlimlerin sultânı faziletlilerin bürhânı zamanının allâmesi ve keşşâfı, hacdan dönerken vefat eden ve Tebük'de medfun bulunan merhum es-Seyyid Abdurrahman er-Rûmî ibn eş-Şeyh eşşehîd Abdullah es-Seyyid de Receb el-Kayserî el-Âmidî'den, o İbrahim elKaramanî'nin talebesi Kayseri'de Müfti Ali en-Nisârî'den, o ikisi de el-Ferîd Süleyman eş-Şirvânî'den, ona da Yahya b. et-Tebrîzî o Habibullah Mirzacân eşŞîrâzî'den, o talebelerin en faziletlisi dinin cemâli Mahmud eş-Şîrâzî el-Gâzî (?); bütün ilimlerde allâme es-Sıddık ed-Devvânî, çok sayıda âlimden ilim almıştır onların en büyügüu ise babası Esad ed-Devvânî ve el-Kazerûnî o ikisi allâme eşŞerîf el-Cürcânî'den istifade etmişlerdir. Onlar Şerif el-Cürcânî'den ilim almakla iftihar ederlerdi. O da Mübârek Şah'ın öğrencisidir. O Kutbuddin er-Râzî'nin o allâme eş-Şîrâzî'nin, o el-Kâtib el-Kazvinî'nin, o İmam Fahreddin er-Râzî'nin, o Hüccetü'l-İslâm İmam el-Gazzâlî'nin, o İmamü'l-haremeyn Abdülmelik b. Abdullah Yusuf el-Cevnî'nin, o babası ibnü't-tabîb ibn Muhammed b. Süleyman es-Salukî'nin, o da Ebî İshak el-Mervezî'nin, o Ebul Abbas Ahmed'in, o Ebul Kasım Osman'ın, o Ebî İbrahîm İsmail'in, o İmam Abdullah b. Muhammed b. İdris eş-Şâfiî'nin, o İmam Muhammed ve el-Hasen eşŞeybânî'nin, o Ebû Hanîfe olarak bilinen dinin kandili mevlânâ Numan b. Sâbit'ten (Allah ona rahmet eylesin, bizi onunu şefaatine nail kılsın), o Hammâd b. Süleyman'dan, o İbrahim Zeyd en-Nehaî'den, o Alkame b. Zeyd ve Ebû Abdurrahman b. Abdullah b. Habib'den, ilk ikisi Abdullah b. Mesud (ra)'dan dan üçüncüsü Ali b. Ebû Talip (ra)'dan, onlar da nebîlerin sonuncusu ve âlemlerin Rabbi'nin elçisi Muhammed Mustafa (sav)'den (salât ve selâm onun 
ve onun âl ve ashâbının üzerine olsun) o da Cibrîl (as)'dan Cebrâil de Allah Teâlâ'dan zirâ O'nun ihsanı her şeyi kuşatmıştır.

Hocaların hocası merhum Muhammed el-Hafîd Ali en-Nesârî de âlim, fâzıl kâmil önde gelen âlimlerden Muhammed ed-Dârendevî'den, o da Saçaklı-zâde olarak meşhur olan merhum fâzıl Muhammed ibn Ebû Bekir el-Maraşî'den icâzet almıştır. O Hamza ed-Dârendevî'ye müntesip idi. Hamza ed-Dârendevî Muhammed et-Tefsîrî'nin icazet verdiklerinin en meşhuru idi. o da Ali elGürânî ve Zeynelabidin Gürânî'den feyz almıştır. Bu ikisi de eş-Şayh Abdullah el-Cezerî̀nin öğrencilerinden idi. o Ahmed el-Müncelî'nin arkadaşlarından, Habibullah Mirzacan'in talebelerinden idi. bana hocamın hocasının hocası ilmiyle âmil, güzel vasıflarla muttasıf şeyhu'ş-şuyûh Yasinci-zâde olarak bilinen Osman icâzet verdi. Ona da ulemanın büyüklerinden Ali b. Hüseyin elKilîsî, ona da doğu ile batı arasında meşhur, tıpkı yıldızlar arasında güneş gibi ilmiyle parlayan Ahmed b. Muhammed el-Kazâbâdî, o Hasan Erzurumî'den Hidâyetü'd-Dirâye ve Kifâyetü'r-Rivâye isimli eseri okumuştur. Sonra Zorlu-zâde olarak meşhur olan et-Tokâdî'den okumuştur. Sonra hocaların hocası zamanının kutbu ve zamanının Numân'ı Muhammed et-Tefsîrî'den, hocasının hocasının hocası zamanının yegânesi, ilimde emsali olmayan babası es-Seyyid el-Hâc Ahmed b. Mustafa'dan okudu. O şöyle dedi: ben babam el-Hâc Yusuf b. İbrahim'in yanında iken birçok ilim dalında ondan feyz aldım. O, Müftü-zâde olarak meşhur olan Muhammed'den, o gençliğinde âlet ve nakli ilimlerde fazilet ve ilim sahibi Hidâyetü'd-Dirâye ve Kifâyetü'r-Rivâye okumuştur. Yine zamanının Numan'ı olan asrının yegânesi bulunan el-Hâc Emir-zâde'den meânî ve usul ilimlerinde ve birçok ilimde istifade etmiştir. İsmail Gelenbevî'nin telifâtından ve kıymetli yazılarından (Allah onların kabirlerini nurlandırsın, bizi onlarla Refîk-i Alâda haşretsin, bu Allah'a güç değildir ${ }^{37}$ ) çokça istifade etmiştir.

Bu abd-i fakir Allah'ın inayetine muhtaç kul der ki, koca dağlar gibi büyük ve seçkin âlimlerin meclislerinde bulundum. Onlardan biri daha önce ismi geçen temiz sîret ve ahlak sahibi es-Seyyid el-Hâfız Ahmed Nureddin Efendi ibn elHâc Mehmed el-Balıkesirî (Allah onun ömrünü uzatsın, iyilikleri ve güzellikleri kata kat versin), onlardan bir diğeri de el-Hâc Mehmed Efendi el-Malatyevî (Allah ona ebedî lütfuyla ikramda bulunsun), yine feyiz aldığı âlimlerden biri ilim meydanının süvarisi huzur derslerinin mukarriri, Haremeyn pâyesine sahip, Aynî Efendi el-Ermenekî diye bilinen es-Seyyid Muhammed (Allah isteklerini ona versin), yine bu âlimlerden âbid, zâhid Ateş-zâde olarak bilinen Mustafa Vehbi Efendi ibn Süleyman et-Tokâdî (Allah onun şanını artırsın ve devam ettirsin), yine fazilet sahiplerinin önde geleni, ilim sahibi filozof

\footnotetext{
${ }^{37}$ Fâtır 35/17. 
Abdülkerim Efendi el-Amasyevî (Allah onu Cennetine koysun) ve yine âlim, fâzıl Hüseyin Efendi el-Kütahyevî'dir (Allah onu ezilî lütfuyla aziz kılsın).

Ey kardeş sana Allah'a itaat ve takvayı, onun hukukunu gözetmeni tavsiye ederim. Sözlerimi kâinatın efendisinin sözleriyle sonlandırırım. O buyurmuştur ki; “

Muaz (ra)'in rivayetine göre Resûlüllah (sav) elimi tuttu ve bir süre yürüdü. Sonra yâ Muaz! Sana Allah'tan korkmanı, doğru sözlü olmanı, ahde vefa göstermeni, emanete riâyet etmeni, hyyaneti terk etmeni, yetime merhamet etmeni, komşularını gözetmeni ve yumuşak sözlü olmanı, selamı yaymanı, fukarayı gözetmeni, âhireti unutmamanı, savaşta sabır göstermeni kısa emel ve güzel ameli, salih müslüman olarak ve yalancıyı tasdik etmemeni, doğruyu yalanlamamanı, adil imama asî olmamanı yeryüzünde fesat çıkarmamanı tavsiye ederim" buyurdu.

Yâ Muâz! Her zaman her yerde Allah'ı zikret! Gizli âşikâr her günahina tevbe et! Bu hadisi Beyhakî rivâyet etmiştir. İki şeyi unutma, hatırla, iki şeyi de unut. Hatırlayacağın iki şey Allah ve ölüm, unutacağın iki şey ise başkalarına yaptığın iyilikler ve başkalarının sana yaptığı kötülükler. Bunlar adaveti dostluğa dönüştüren hasletlerdir.

Ebû Hanife (rahimehullah) gibi Eşbah'ın sonunda talebeleri Yakub ve İmam Ebû Yusuf ve oğlu Hammad'a nesihatlerde bulunduğu Zübdetü'n-Nesâyih denilen eserde sana hakikati gösterecek selefin tavsiyelerine göz at! Üstaz Hâdimî öncekilerin ve sonrakilerin nasihatlerini/tavsiyelerini bir risalede toplamiştır.

Allah bizi ve seni kendisine karşı samimi ve ihlaslı olma konusunda muvaffak kılsın. Çünkü nasihat kolaydır, onu kabul edip tutmak zordur. Senden beni hayır duada unutmamanı isterim.

"Rabbimiz! Bizi doğru yola erdirdikten sonra kalplerimizi eğriltme, katından bize rahmet bağışla; şüphesiz sen sonsuz bağışta bulunansın." 38 Rabbimiz! Beni, ana-babamı, hocalarımı, üzerimde hakları olanları, bana hayrı tavsiye edenleri ve bütün müminleri kıyamet günü bağışla! Rabbimiz! Bize dünyada iyilik ver, ahirette de iyilik ve güzellikler ver ve bizi Cehennem azabından koru! Ya Azîz, yâ Gaffâr/ey bağışlayan bizi rahmetinle iyilerle birlikte Cennetine dâhil et! Allah'tan başka ilah yoktur Muhammed (sav) O'nun kulu ve resulüdür. Son sözümüz İnşâallah, ve'l-hamdülillah, İzzet ve Celal sahibi Allah'ın izniyle bu olsun. Bu benim âklî ve naklî ilimleri tahsil ederek hocam es-Seyyid el-Hâfız

38 Âl-i imran 3/8. 
Ahmed Nureddin Efendi ibn el-Hâc Muhammed (Allah onu isteklerine nail kılsın ve onu bütün âfetlerden selamette kılsın, Allah onu mesut eylesin) tarafından verilen icâzet-nâmemin sûretidir. Ben de Allah'ın (cc) günahkâr, değersiz aczini itiraf eden kulu, Sultân Bâyezîd-ı Velî Camii müderrislerinden es-Seyyid Muhammed Lütfi ibn el-Hâc Lütfullah-zâde Ahmed el-Firecikî (Allah onu mağfiretine gark eylesin) bu icazetname 1315/1897-98 y1lında yazıldı. Allah'ım bizden resulün ve habibin Muhammed Mustafa (sav) hatırına kabul buyur.

Mühür

Muhammed Lütfü

$1304 / 1886-87$

\section{Sonuç}

Hafız Osman Nuri Efendi 1282/1866-67 tarihinde Tekirdağ'da doğmuş, hafızlığını ve ilk tahsilini memleketinde yaptıktan sonra yüksek tahsilini tamamlamak üzere İstanbul'a gelmiştir. Burada Sultân Bâyezîd Camii müderrislerinden es-Seyyid Muhammed Lütfi ibn el-Hâc Lütfullah-zâde Ahmed el-Firecikî'den (Tefsir, hadis, fıkıh, kelam gibi) ulûm-i 'âliye ve (sarf, nahiv, mantık, belgat gibi) ulûm-i 'âliye tahsil etmiş ve icâzet-nâme almıştır. Osman Nuri Efendi uzun süre devlet hizmetine girmemiş ancak, Kilitbahir'de Nakşibendî Şeyhi Kazanlıklı Hacı Ahmed Efendi'ye intisap etmiş, bilahare onun halifesi olmuştur. Memuriyete Maydos/Eceabâd müftüsü olarak başlamış ve Eceabâd müderrisliğinde bulunmuştur. Müderrisliği boyunca okuttuğu dersler ve yetiştirdiği talebelere dair bilgiye ulaşılamadığı gibi telif ettiği bir eser ve risale de tespit edilememiştir. Tekirdağ idare meclisinde yapılan seçimde en fazla oyu alarak Tekirdağ Müftülügüne tayin edilmiştir. Görev yaptığı yıllarda Tekirdağ'ın Yunanlılar tarafından işgaline bizzat şahit olmuştur. Tedavi amacıyla kullandığı izinlerden bir takım sağlık problemleri yaşamış aylarca dizlerinden, ayaklarından ve kulaklarından tedavi gördüğü anlaşılmaktadır. Ailesine ve vefatına ilişkin sicil dosyasında bilgi yoktur. Hafız Osman Nuri Efendi'nin biyografisi ve icâzet-nâmesine ilişkin bu çalışma, bundan sonra yapılacak çalışmalara bir başlangıç olması temenni edilmektedir. 


\section{Kaynakça}

İST. MFT, MŞH, SAİ, 62/19.

Düstur, c. 9, 2. Tertip, İstanbul 1928.

Albayrak Sadık, Son Devir Osmanlı Ulemâsı, İstanbul, İstanbul Büyükşehir Belediyesi Kültür İşleri Daire Başkanlığı Yayınları, 1996.

Cemil Akpınar, "İcâzet”, İstanbul, DİA, XXI, 2000.

İpşirli Mehmet, “Dersiâm”, İstanbul DİA, IX, 1994.

İpşirli Mehmet, “İlmiye”, İstanbul DİA, XXII, 2000.

İpşirli Mehmet, “Müderris”, İstanbul, DİA, XXXI, 2006.

Karaman, Hayrettin; Özek, Ali; Dönmez, İbrahim Kâfi; Çağrıcı, Mustafa; Gümüş, Sadrettin; Turgut, Ali, Kur'an-ı Kerim ve Açıklamalı Meali, İstanbul, Marmara Üniversitesi, İlahiyat Fakültesi Vakfı Yayınları, 3. baskı, 1990.

İlber Ortaylı, “Kadı”, İstanbul, DİA, XXIV, 2001.

Pakalın Mehmet Zeki, Osmanlı Tarih Deyimleri ve Terimleri Sözlüğ̈̈, İstanbul, MEB, II, 1996. 
Ekler

1. Hâfız Osman Nuri Efendi'nin terceme-i hâl evrâkı

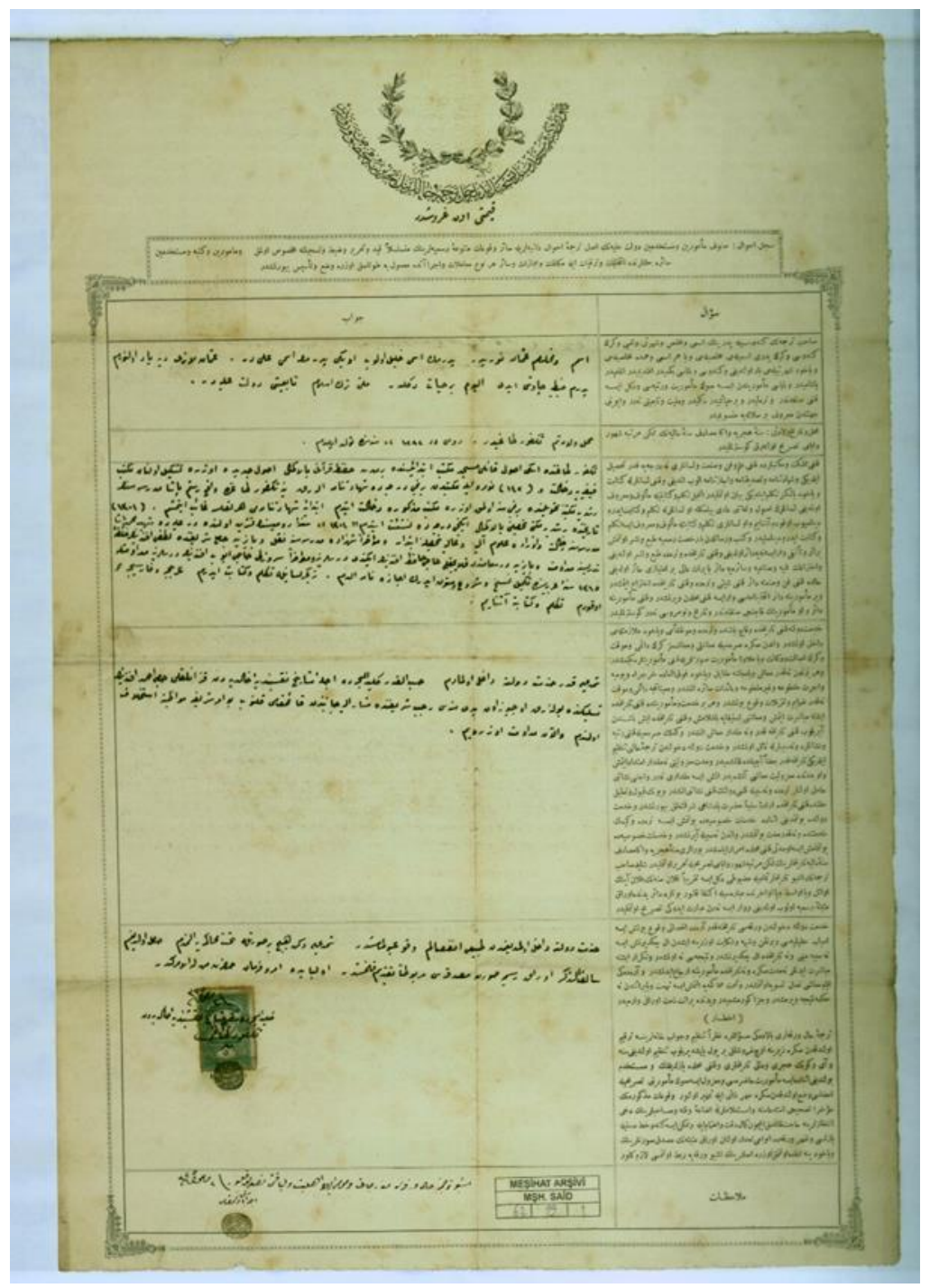


Tekfurdağlı Bir Âlim; Osman Nuri Efendi ve İcâzet-nâmesi/ Osman Nuri Effendi, a Scientist of Tekfurdag; and His Ijazatnamah (License to Teach)

\section{2- Hâfız Osman Nuri Efendi'nin icâzet-nâmesi}
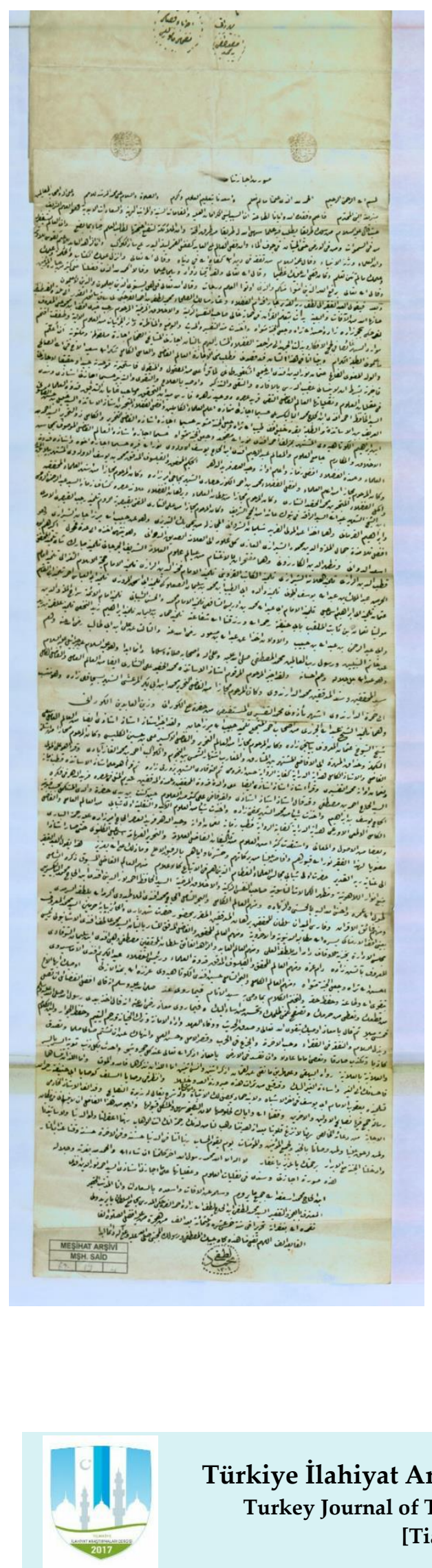

Türkiye İlahiyat Araştırmaları Dergisi Turkey Journal of Theological Studies ISSN: 2602-3067 [Tiad] 